\title{
Perbandingan Reaksi Pasar di AS, China dan Indonesia terhadap Perundingan Perang Dagang AS-China
}

\author{
Giovaninho Ferreira Da Costa ${ }^{1}$ \\ Fakultas Ekonomi dan Bisnis \\ Universitas Udayana, Indonesia
}

\author{
I Made Sukartha ${ }^{2}$ \\ Fakultas Ekonomi dan Bisnis \\ Universitas Udayana, Indonesia
}

Surel : dacostagiovaninho@gmail.com

\section{ABSTRAK}

Penelitian ini bertujuan untuk menguji reaksi pasar di pasar saham Amerika, China dan Indonesia atas pengumuman hasil perundingan perang dagang AS-China. Peristiwa perundingan perang dagang dilaksanakan pada tanggal 10-11 oktober 2019. Penelitian ini menggunakan metode event study dan metode pemilihan sampel secara purposive. Populasi pada penelitian ini terdiri dari indeks saham Dow 30, SSE 50 dan LQ45 dengan total sampel sebanyak 123 perusahaan. Variabel yang digunakan adalah data Cumulative Abnormal Return (CAR) dari indeks saham Dow 30, SSE 50 dan LQ45 di jendela peristiwa. Berdasarkan hasil analisis ditemukan bahwa terdapat reaksi pasar di pasar saham Amerika, China dan Indonesia atas pengumuman hasil perundingan perang dagang AS-China. Jadi terdapat kandungan informasi atas peristiwa tersebut. Hasil penelitian juga menunjukan bahwa terdapat perbedaan reaksi di antara pasar saham Amerika, China dan Indonesia atas pengumuman hasil perundingan perang dagang AS-China.

Kata Kunci: Reaksi Pasar; Cumulative Abnormal Return; Perundingan Perang Dagang.

\section{Comparison of Market Reactions in the US, China, and Indonesia Against the US-China Trade War Negotiations}

\begin{abstract}
This study aims to examine the market reaction in the American, Chinese, and Indonesian stock markets about the announcement of the results of the US-China trade war negotiations. The events of the trade war negotiations took place on 10-11 October 2019. This research used the event study method and the purposive sampling method. The population in this study consisted of Dow 30, SSE 50 and LQ45 stock indices with a total sample of 123 companies. The study used Cumulative Abnormal Return (CAR) as a variable which was data from the Dow 30, SSE 50, and LQ45 stock indices during the event window. Based on the results of the analysis, it was found that there was a market reaction on the American, Chinese, and Indonesian stock markets on the announcement of the results of the US-China trade war negotiations. So there is information content for the event. The results also showed that there were differences in reactions between the American, Chinese, and Indonesian stock markets on the announcement of the results of the US-China trade war negotiations.
\end{abstract}

Keywords: $\quad$ Market Reaction; Cumulative Abnormal Return; Trade War Negotiations.

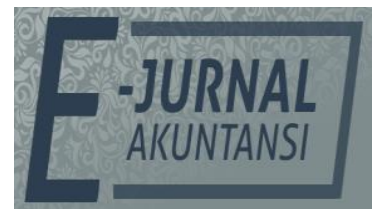

e-ISSN 2302-8556

Vol. 30 No. 9

Denpasar, September 2020 Hal. 2270-2280

DOI:

10.24843/EJA.2020.v30.i09.p08

PENGUTIPAN:

Costa, G. F. D. \& Sukartha, I

M. (2020). Perbandingan

Reaksi Pasar di AS, China

dan Indonesia terhadap

Perundingan Perang Dagang

AS-China. E-Jurnal

Akuntansi, 30(9), 2270-2280

RIWAYAT ARTIKEL:

Artikel Masuk: 22 Juni 2020

Artikel Diterima: 27 September 2020

Artikel dapat diakses : https://ojs.unud.ac.id/index.php/Akuntansi/index 


\section{PENDAHULUAN}

Harga saham selalu berfluktuasi dan mengakibatkan dua kemungkinan yaitu kenaikan harga yang bisa memberikan keuntungan (capital gain) atau penurunan harga yang dapat menimbulkan kerugian (capital loss) (Caskey et al., 2012). Harga saham di pasar modal sangat dipengaruhi oleh berbagai informasi (Hasdwi Putra \& Dwija Putri, 2018), (Wahyudhi \& Agung Suaryana, 2019), dan (Wahyudi \& Putra, 2020). Informasi yang dapat mempengaruhi harga saham adalah semua informasi yang mempengaruhi nilai perusahaan (Knauer \& Wöhrmann, 2016), (Kori \& Rasmini, 2017), dan (Ratnaningsih \& Widanaputra, 2019). Menurut Alwi (2003) investasi dalam saham dapat dipengaruhi oleh lingkungan internal dan eksternal perusahaan. Lingkungan internal merupakan faktor yang berhubungan dengan perusahaan itu sendiri (misalnya pergantian $C E O$, kebijakan dividen) sedangkan lingkungan eksternal merupakan faktor yang berhubungan dengan ekonomi maupun non ekonomi diluar kendali perusahaan (kebijakan politik, kebijakan ekonomi, resesi ekonomi) (Armstrong et al., 2010), dan (Grewal et al., 2019). Dalam kurun waktu satu tahun terakhir salah satu faktor yang mempengaruhi ekonomi global dan juga harga saham yaitu perang dagang antara Amerika Serikat (AS) dan China.

Perang dagang adalah konflik ekonomi yang terjadi ketika suatu negara memberlakukan atau meningkatkan tarif atau hambatan perdagangan lainnya sebagai balasan terhadap hambatan perdagangan yang ditetapkan oleh pihak yang lain (Chen, 2019). Perang dagang antara Amerika Serikat dan China dimulai dengan pengenaan tarif bea masuk oleh bagian pemerintahan Donuld Trump sebesar 30\% hingga 50\% untuk impor panel surya dan mesin cuci pada 22 Januari 2018. Kemudian pada tanggal 8 maret 2018 Amerika Serikat menaikkan tarif bea tambahan untuk barang impor baja sebesar $25 \%$ dan aluminium sebesar 10\% dari sejumlah negara. Pada 22 maret 2018 China merespon dengan mengenakan tarif bea masuk sebesar 15\%-25\% dari 128 produk dari Amerika Serikat. Sejak saat itu, kedua negara saling membalas untuk menaikkan tarif pajak bagi berbagai barang impor dari masing-masing negara.

Terdapat dua alasan mengapa pemerintahan di era Trump memulai perang dagang dengan mengenakan kenaikan tarif pajak pada berbagai barang impor dari China (Havráneková \& Dvorský, 2019) yaitu: 1) defisit perdagangan yang dialami oleh Amerika serikat ketika melakukan perdagangan dengan China yaitu sebesar $\$ 375.23$ miliar pada tahun 2017 (Amerika mengimpor barang dari China sebesar $\$ 505.469$ miliar dan ekspor sebesar $\$ 129.89$ miliar) dimana hal tersebut dapat mengakibatkan produk-produk yang dihasilkan perusahaan setempat akan susah/gagal dalam persaingan pasar, dan 2) Amerika Serikat menganggap China menangkal hak kekayaan intelektual perusahaan (yaitu dengan mentransfer teknologi Amerika dan kekayaan intelektual ke perusahaan di China ) dengan undang-undang China yang secara ketat mendikte perusahaan asing untuk terlibat dalam usaha patungan (joint venture) dengan entitas China.

Pada penelitian ini, peneliti bertujuan untuk menguji respon pasar saham di Indonesia pada perang dagang antara Amerika dan China. Menurut riset yang dilakukan oleh Morgan Stanley, perang dagang tersebut menjadi salah satu faktor yang menghambat perkembangan perekonomian Indonesia, yang sebelumnya diperkirakan sebesar 5,3\% turun menjadi 5\%. Namun, menurut 
Stanley dampak dari perang dagang antara kedua negara tersebut tidak terlalu berpengaruh signifikan terhadap kestabilan ekonomi Indonesia dikarenakan konsumsi dari masyarakat yang relatif tinggi (Stanley, 2019). Konflik ekonomi tersebut juga berpengaruh pada IHSG. Misalnya, pernyataan Trump yang mengancam menaikkan tarif impor barang dari China menjadi $25 \%$ dengan nilai \$200 miliar direspon negatif pasar, yaitu berdampak terhadap melemahnya IHSG sebesar 1,15\% dan indeks saham LQ45 menurun 1,57\% (liputan 6, 2019). Selain itu, IHSG melemah $1,19 \%$ saat pemerintahan China mengumumkan balasan kenaikan tarif pada 13 mei 2019 dan IHSG kembali melemah pada pembukaan bursa saham sebesar $0,88 \%$ di hari setelahnya. IHSG dan indeks LQ45 masing-masing melemah $0,98 \%$ dan 1,4\% pada 6 Agustus 2019 saat pemerintahan China kembali membalas kenaikan tarif pajak dari Amerika. Sedangkan, IHSG menguat sebesar 0,25\% pada tanggal 9 September 2019 dikarenakan rencana pertemuan America Serikat dengan China membahas soal perundingan perang dagang antara keduanya dan pada 11 oktober 2019 perundingan perang dagang antara AS dan China berjalan dengan baik dengan harapan bahwa akan berakhirnya perang dagang, IHSG menguat sebesar 1,03\% dan indeks LQ45 naik sebesar 1,26\%. Jadi, kebijakan kenaikan tarif oleh pemerintahan AS dan China berdampak terhadap pelemahan bursa saham di Indonesia. Dengan demikian, peneliti tertarik untuk meneliti tentang reaksi pasar saham di Indonesia terhadap peristiwa tersebut.

Selain itu, peneliti juga bertujuan untuk meneliti tentang reaksi pasar saham di Amerika dan China yang merupakan pelaku utama dari perang dagang tersebut. Hambatan perdagangan yang diberlakukan oleh AS-China sangat berpengaruh pada pertumbuhan ekonomi di kedua negera tersebut. Selain itu, perang dagang ini juga menurunkan pertumbuhan ekonomi global 2019 yang sebelumnya diprediksi akan mencapai 3,2\% menjadi 3\% saja (IMF, 2019). Peningkatan tekanan dari perang dagang ini juga dapat berdampak buruk terhadap aliran kredit baru, dan dapat mengurangi atau menahan investasi, produksi dan perdagangan. Selama perang dagang antara Amerika dan China ini berlangsung, hal tersebut sangat merugikan bagi keduanya, dilihat dari penurunan ekspor dan impor antara kedua negara, dan juga penurunan investor asing antara keduanya. Selain itu, berdampak juga terhadap fluktuasi harga saham yang cukup signifikan di kedua negara yang saling membalas kenaikan tarif pada produk impor masing-masing. Misalnya index S\&P 500 naik 0,81\% pada saat Presiden Donuld Trump mengumumkan kenaikan tarif pajak untuk impor panel surya dan mesin cuci pada 22 Januari 2018 dan pada 8 maret 2018, ketika terdapat kenaikan tarif lagi untuk produk impor aluminium dan baja, index S\&P 500 naik sebesar $0,45 \%$. Namun index S\&P 500 mengalami penurunan sebesar 2,23\% pada saat pemerintahan China membalas kenaikan tarif dari Amerika dengan menaikan tarif sebesar 25\% untuk 128 produk impor dari Amerika pada 22 Maret 2018. Menurut Ozturk \& Altinuz (2019) bahwa kenaikan tarif pajak yang diberlakukan oleh Amerika berpengaruh terhadap penurunan index harga saham Shanghai.

Penelitian ini akan menguji tentang apakah terdapat kandungan informasi pada pasar saham di Amerika, China dan Indonesia ketika pengumuman hasil perundingan perang dagang antara Amerika dan China. Jika 
suatu peristiwa atau pengumuman mengandung informasi, maka diharapkan pasar saham akan bereaksi pada saat peristiwa atau pengumuman tersebut diterima. Reaksi dari pasar dapat diukur dengan menggunakan abnormal return. Abnormal return merupakan kelebihan dari return yang sesungguhnya terjadi terhadap return normal (Hartono, 2017). Oleh karena itu, dapat dikatakan bahwa, pengumuman yang mempunyai kandungan informasi akan memberikan return yang tak normal pada pasar (Hartono, 2010).

Studi yang mempelajari dan menguji reaksi dari pasar saham terhadap suatu peristiwa atau pengumuman yang dipublikasikan adalah event study (Hartono, 2017). Event study juga menganalisis abnormal return dari sekuritas yang dapat terjadi di sekitar pengumuman dari suatu peristiwa (Hartono, 2017). Peristiwa yang diteliti pada penelitian ini yaitu peristiwa perundingan perang dagang antara Amerika dengan China. Perundingan perang dagang antara Amerika dan China dilaksanakan pada tanggal 10 dan 11 oktober 2019. Perundingan ini merupakan fase pertama antara kedua negara tersebut yang bertujuan untuk mengakhiri gejolak perang dagang yang berlangsung selama lebih dari satu tahun ini. Semenjak awal, perang dagang antara kedua negara tersebut mengakibatkan fluktuasi harga saham. Negosiasi antara kedua negara tersebut berakhir dengan beberapa kesepakatan, yaitu diantaranya adalah: (1) China sepakat akan membeli produk pertanian AS sebesar $\$ 40-\$ 50$ miliar setiap tahun, (2) memperkuat ketentuan hak kekayaan intelektual (intellectual property right) di China dan pembatalan kenaikan tarif terhadap barang impor China yang dijadwalkan pada 15 oktober 2019.

$\mathrm{H}_{1}$ : Terdapat reaksi pasar pada saat pengumuman hasil perundingan perang dagang antara Amerika dan China.

$\mathrm{H}_{1 \mathrm{a}}$ : Terdapat reaksi pasar di pasar saham Amerika pada saat pengumuman hasil perundingan perang dagang Amerika dan China.

$\mathrm{H}_{1 \mathrm{~b}}$ : Terdapat reaksi pasar di pasar saham China pada saat pengumuman hasil perundingan perang dagang Amerika dan China.

$\mathrm{H}_{1 \mathrm{c}}$ : Terdapat reaksi pasar di pasar saham Indonesia pada saat pengumuman hasil perundingan perang dagang Amerika dan China.

Tandelilin (2010) menyatakan bahwa konsep pasar yang efisien merupakan pasar yang akan bereaksi positif pada berita baik dan sebaliknya akan bereaksi negatif jika berita buruk yang diterima. Menurut Beaver (1989) menyatakan bahwa efisiensi pasar merupakan hubungan antara harga-harga sekurias dengan informasi yang tersedia. Konsep pasar efisien menjelaskan bagaimana pasar bereaksi pada informasi-informasi yang diterima, dan bagaimana pengaruh dari informasi tersebut pada terbentuknya harga keseimbangan yang baru (Tandelilin, 2010). Jadi, jika hasil pengumuman perundingan perang dagang AS-China merupakan berita baik, pasar akan bereaksi positif, tetapi jika merupakan berita buruk, maka pasar akan bereaksi negatif.

Tri (2019) menyimpulkan bahwa peristiwa perang dagang AS-China memberikan pengaruh negatif terhadap abnormal return pada 41 perusahaan yang terdaftar di BEI. Huang et al. (2018) menyatakan bahwa perusahaanperusahaan di AS yang berhubungan langsung dengan entitas China dalam ekspor dan impor memiliki stock return yang rendah, dikarenakan perang dagang 
AS-China. Menurut hasil penelitian Egger \& Zhu (2019) pasar saham Amerika dan China bereaksi negatif pada saat pengumuman kenaikan tarif pajak impor selama perang dagang antara Amerika dan China. Selain itu, pasar saham di negara pihak ketiga juga bereaksi negatif.

Oleh karena selama gejolak perang dagang AS-China berlangsung menimbulkan reaksi yang negatif dari pasar saham maka dengan adanya peristiwa perundingan perang dagang tersebut diharapkan dapat menimbulkan reaksi yang positif dari pasar saham. Maka berdasarkan latar belakang, teoriteori pendukung dan beberapa penelitian terdahulu maka hipotesis dalam penelitian ini adalah sebagai berikut.

$\mathrm{H}_{2}$ : Terdapat perbedaan reaksi pada pasar saham Amerika, China dan Indonesia saat pengumuman hasil perundingan perang dagang antara Amerika dan China.

\section{METODE PENELITIAN}

Lokasi penelitian ini dilakukan pada perusahaan-perusahaan yang terdaftar di Dow Jones Industrial Average (DJIA) atau biasa disebut Dow 30, SSE 50 index dan indeks LQ45 periode 2019. Penelitian ini menggunakan data sekunder yang diperoleh dari website www.us.spindices.com, www.csindex.com.cn, www.ksei.co.id, serta data harga saham harian yang didapat melalui situs www.finance.yahoo.com. Objek penelitian ini adalah abnormal return disekitar tanggal peristiwa perundingan perang dagang antara Amerika dan China.

Penelitian ini menggunakan jenis data kuantitatif yakni data yang berupa angka-angka ataupun rasio dan menggunakan sumber data sekunder berupa data historis seluruh perusahaan yang terdaftar dalam indeks LQ45, Dow 30 dan SSE index 50 periode 2019 yang diunduh melalui situs www.finance.yahoo.com.

Populasi dari penelitian ini adalah perusahaan yang terdaftar dalam indeks LQ45, Dow 30 dan SSE index 50 periode 2019. Alasan menggunakan saham perusahaan yang terdaftar dalam indeks LQ45 karena sahamnya memiliki karakteristik dengan tingkat likuiditas yang tinggi sehingga mudah untuk diperdagangkan dan memiliki kapitalisasi yang relatif besar di Bursa Efek Indonesia. Sedangkan, Dow Jones 30 dan SSE index 50 merupakan salah satu index yang terpercaya di Amerika dan China yang memiliki kapitalisasi pasar tertinggi, yang diharapkan dapat merepresentasikan pasar saham di kedua negara tersebut. Oleh sebab itu, dengan menggunakan saham perusahaan yang terdaftar dalam indeks LQ45, Dow 30 dan SSE index 50 diharapkan dapat memperoleh hasil yang lebih akurat dalam mencerminkan reaksi pasar modal di Indonesia, Amerika dan China terhadap peristiwa perang dagang ini. Sampel yang terpilih di penelitian ini adalah perusahan-perusahan yang tergabung dalam indeks LQ45, Dow 30 dan SSE 50 selama periode estimasi dan jendela peristiwa, perusahaan dalam periode jendela peristiwa tidak melakukan aksi korporasi (corporate action) seperti akuisisi, pembagian dividen, pergantian CEO dan selama periode estimasi dan jendela peristiwa yang ditentukan, sahamsaham yang dimiliki perusahaan aktif diperdagangkan (bukan saham tidur).

Metode pengumpulan data yang digunakan dalam penelitian ini yaitu menggunakan metode observasi non-partisipan. Observasi dilakukan dengan mengumpulkan teori-teori yang dapat digunakan sebagai landasan yang 
berhubungan dengan permasalahan yang diteliti. Data yang diperlukan dalam penelitian ini yakni berupa data sekunder yang dapat diperoleh dengan mengakses situs website sebagai berikut www.us.spindices.com, www.csindex.com.cn, www.ksei.co.id, dan www.finance.yahoo.com.

Salah satu teknik analisis data yang digunakan dalam penelitian ini adalah one sample t-test. One sample t-test dapat digunakan dengan syarat apabila data berupa kuantitatif dan memiliki distribusi normal. Tetapi jika data berdistribusi tidak normal maka akan digunakan one sample chi square. Pengujian one sample ttest dilakukan untuk mengetahui terdapat atau tidaknya reaksi pasar yang signifikan atas peristiwa pengumuman pada perundingan perang dagang antara Amerika Serikat dan China pada 11 Oktober 2019 yang dilihat dari abnormal return pada sekitar tanggal peristiwa. Jika data berdistribusi normal dengan menentukan tingkat signifikansi $(\alpha)=5 \%$, maka jika nilai signifikansi (2-tailed) $<$ 0,05 maka H1 diterima dan jika nilai signifikansi (2-tailed) > 0,05 maka H1 ditolak.

Pengujian one way anova bertujuan untuk mengetahui ada atau tidaknya perbedaan rata-rata antara dua atau lebih kelompok sampel yang berbeda. Pengujian ini dilakukan untuk mengetahui terdapat atau tidaknya perbedaan reaksi pasar di Amerika, China dan Indonesia pada saat terlaksananya perundingan perang dagang antara Amerika dan China. Pengujian one way anova dilakukan apabila data berdistribusi normal, jika tidak, maka pengujian ini akan menggunakan metode uji komparatif $\mathrm{K}$ sampel independen dengan rumus Kruskal Wallis. Jadi dengan tingkat signifikansi $(\alpha)=5 \%$, apabila uji one way annova mendapatkan hasil sebagai berikut, maka dasar pengambilan keputusannya adalah jika nilai signifikansi (2-tailed) $<0,05$ berarti $\mathrm{H}_{2}$ diterima dan jika nilai signifikansi (2-tailed) $>0,05$ berarti $\mathrm{H}_{2}$ ditolak.

\section{HASIL DAN PEMBAHASAN}

Statistik deskriptif digunakan untuk memberikan informasi mengenai karakteristik variabel penelitian berupa jumlah sampel, nilai maksimum, nilai minimum, nilai rata-rata (mean), dan standar deviasi (deviation standard). Berikut hasil statistik deskriptif yang dapat dilihat pada Tabel 1.

Tabel 1. Hasil Uji Statistik Deskriptif

\begin{tabular}{lccccc}
\hline & N & Maximum & Minimum & Mean & $\begin{array}{l}\text { Std. } \\
\text { Deviation }\end{array}$ \\
\hline CAR Dow 30 & 29 & 0,08935 & $-0,05328$ & 0,01914 & 0,03067 \\
CAR SSE 50 & 50 & 0,14814 & $-0,05710$ & 0,03229 & 0,03455 \\
CAR LQ45 & 44 & 0,16300 & $-0,09640$ & 0,05077 & 0,05192 \\
\hline
\end{tabular}

Sumber: Data Penelitian, 2020

Berdasarkan Tabel 1, cumulative abnormal return (CAR) indeks saham Dow 30, SSE 50 dan LQ45 didapat dari perhitungan Abnormal return dari sampel masing-masing indeks sebanyak 29, 50 dan 44 perusahaan selama tujuh hari jendela peristiwa. Nilai CAR maximum dari ketiga indeks tersebut yaitu 0,08935, 0,14814 dan 0,16300 dari perusahaan Caterpillar (indeks Dow 30), China Everbright Bank (indeks SSE 50) dan Indah Kiat Pulp \& Paper (indeks LQ45). Sedangkan, nilai CAR minimum dari ketiga indeks tersebut yaitu -0,05328, 0,05710 dan -0,09640 dari perusahaan Procter \& Gamble (indeks Dow 30), Sanan 
Optoelectronics (indeks SSE 50) dan Indofood CBP Sukses Makmur (indeks LQ45). Hasil mean dari masing-masing indeks didapatkan sebesar 0,01914, 0,03229 dan 0,05077. Sedangkan standar deviasi dari indeks saham Dow 30, SSE 50 dan LQ45 yaitu 0,03067, 0,03455 dan 0,05192.

Uji normalitas bertujuan untuk menguji apakah variabel dalam penelitian ini terdistribusi normal atau tidak. Pengujian normalitas ini menggunakan uji statistik Kolmogorov-Smirnov. Residual dikatakan berdistribusi normal jika nilai signifikansi $>$ a $(0,05)$. Berdasarkan hasil uji normalitas yang dilakukan terhadap CAR dari indeks Dow 30, SSE 50 dan LQ45 bahwa nilai signifikansinya > a $(0,05)$ mengindikasikan bahwa data-data penelitian ini berdistribusi normal. Berikut merupakan tabel uji normalitas yang diperoleh dari uji Statistical Product and Service Solutions (SPSS).

Tabel 2. Hasil Uji Normalitas

\begin{tabular}{lll}
\hline \multirow{3}{*}{ CAR Dow 30} & $\mathrm{~N}$ & 29 \\
\cline { 2 - 3 } & Kolmogorov-Smirnov Z & 0,081 \\
& Asymp. Sig. (2-tailed) & 0,200 \\
CAR SSE 50 & Nolmogorov-Smirnov Z & 50 \\
& N Asymp. Sig. (2-tailed) & 0,091 \\
& N & 0,200 \\
CAR LQ45 & Kolmogorov-Smirnov Z & 0,054 \\
& N Asymp. Sig. (2-tailed) & 0,200 \\
\hline
\end{tabular}

Sumber: Data Penelitian, 2020

Uji one sample t-test digunakan untuk menguji hipotesis 1 . Uji tersebut digunakan karena data pada penelitian ini terdistribusi normal. Fungsi uji one sample t-test di penelitian ini yaitu untuk mengetahui ada tidaknya reaksi pasar pada saat pengumuman hasil perundingan perang dagang. Hipotesis 1 diterima apabila nilai signifikansinya $>$ a $(0,05)$. Berikut merupakan tabel hasi uji one sample t test dari SPSS.

Tabel 3. Hasil Uji One Sample T-Test

Test Value $=0$

\begin{tabular}{|c|c|c|c|c|c|c|}
\hline & & & & $\mathrm{Met}$ & $95 \%$ Co & $\begin{array}{l}\text { ce Interval } \\
\text { erence }\end{array}$ \\
\hline & $\mathrm{T}$ & $\mathrm{df}$ & Sig. (2-tailed) & Difference & Lower & Upper \\
\hline CAR Dow 3 & 03,362 & 28 & 0,002 & 0,01914552 & 0,0074797 & 0,0308114 \\
\hline CAR SSE 50 & 6,608 & 49 & 0,000 & 0,03229100 & 0,0224716 & 0,0421104 \\
\hline CAR LQ45 & 6,487 & 43 & 0,000 & 0,05077432 & 0,0349900 & 0,0665586 \\
\hline
\end{tabular}

Sumber: Data Penelitian, 2020

Hasil cumulative abnormal return (CAR) dari indeks Dow 30 selama jendela peristiwa memperoleh nilai $t=3,362$ dengan nilai probabilitas sebesar 0,002 . Nilai probabilitas $0,002<a(0,05)$, yang berarti hipotesis 1a diterima. Jadi dapat dikatakan bahwa terdapat reaksi pasar di pasar saham Amerika pada saat pengumuman hasil perundingan perang dagang Amerika dan China.

Hasil CAR dari indeks SSE 50 selama jendela peristiwa memperoleh nilai $t$ $=6,608$ dengan nilai probabilitas sebesar 0,000 . Nilai probabilitas $0,000<a(0,05)$, yang berarti hipotesis $1 \mathrm{~b}$ diterima. Jadi dapat dikatakan bahwa terdapat reaksi pasar di pasar saham China pada saat pengumuman hasil perundingan perang dagang Amerika dan China. 
Hasil CAR dari indeks LQ45 selama jendela peristiwa memperoleh nilai $\mathrm{t}=$ 6,487 dengan nilai probabilitas sebesar 0,000. Nilai probabilitas $0,000<a(0,05)$, yang berarti hipotesis 1c diterima. Jadi dapat dikatakan bahwa terdapat reaksi pasar di pasar saham Indonesia pada saat pengumuman hasil perundingan perang dagang Amerika dan China.

Hasil tersebut juga menunjukan bahwa pasar saham China memiliki reaksi yang paling signifikan terhadap pengumuman hasil perundingan perang dagang AS-China dengan nilai t sebesar 6,608.

Jadi secara keseluruhan dapat dikatakan bahwa hipotesis 1 diterima karena nilai probabilitas dari setiap indeks saham $<a(0,05)$. Hal ini berarti bahwa terdapat reaksi pasar di pasar saham Amerika, China dan Indonesia pada saat pengumuman hasil perundingan perang dagang Amerika dan China.

Anova merupakan singkatan dari analysis of variance. Prinsip Uji Anova adalah melakukan analisis variabilitas data menjadi dua sumber yaitu variasi di dalam kelompok (within) dan variasi antar kelompok (between). Uji one way anova adalah tes statistik yang digunakan untuk menganalisis perbedaan rata-rata (mean) antara dua atau lebih dari dua kelompok. Uji one way anova digunakan untuk menguji ada tidaknya perbedaan reaksi pasar antara pasar saham Amerika, China dan Indonesia terhadap hasil perundingan perang dagang ASChina. Berikut merupakan beberapa tabel hasil uji one way annova.

Tabel 4. Hasil Uji One Way Anova

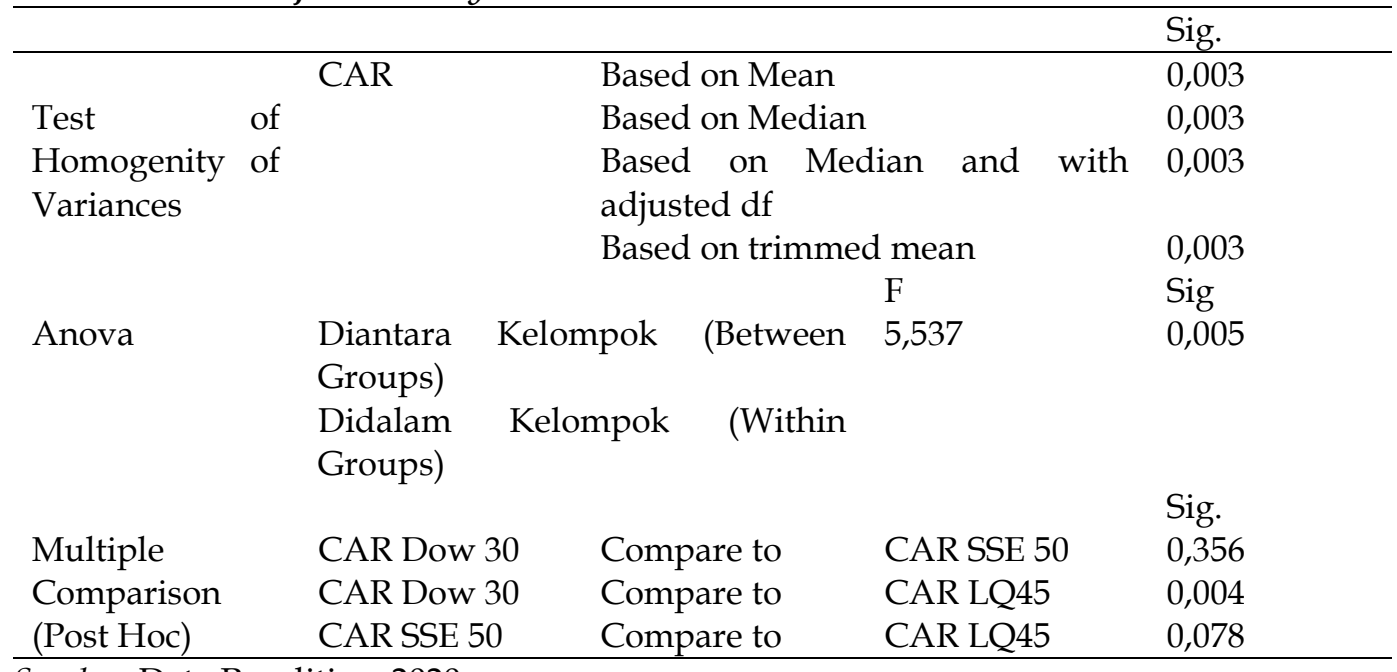

Sumber: Data Penelitian, 2020

Hasil uji homogenitas dari variansi antar kelompok mendapatkan hasil nilai probabilitas sebesar 0,003 < a $(0,05)$ yang berarti bahwa varian antar kelompok homogen. Jadi data dari masing-masing indeks saham layak diuji melalui uji one way anova.

Hasil uji anova diantara kelompok (between groups) mendapatkan nilai $\mathrm{F}$ sebesar 5,537 dengan nilai probabilitas sebesar 0,005 < a $(0,05)$. Hasil tersebut mengindikasikan bahwa hipotesis 2 diterima, yang berarti terdapat perbedaan reaksi pasar pada pasar saham Amerika, China dan Indonesia.

Hasil uji muiltiple comparison (post hoc) merupakan hasil uji lanjutan dari one way anova didalam kelompok (within groups). Hasil uji tersebut memiliki arti bahwa tidak terdapat perbedaan rata-rata (mean) di antara CAR Dow 30 dengan 
CAR SSE 50 dan CAR LQ45 dengan CAR SSE 50 yang memiliki nilai probabilitasnya masing-masing sebesar $0,356>$ a $(0,05)$ dan $0,078>a(0,05)$. Tetapi terdapat perbedaan rata-rata (mean) di antara CAR Dow 30 dengan LQ45 yang memiliki nilai probabilitas sebesar $0,004<\alpha(0,05)$.

Hasil pengujian menunjukan bahwa terdapat reaksi pasar di pasar saham Amerika, China dan Indonesia atas hasil pengumuman perundingan perang dagang Amerika dan China. Hasil pengujian juga menunjukan bahwa terdapat perbedaan reaksi pada pasar saham Amerika, China dan Indonesia atas hasil pengumuman perundingan perang dagang Amerika dan China. Kedua hasil tersebut sesuai dengan hipotesis yang diajukan sehingga $\mathrm{H}_{1}\left(\mathrm{H}_{1 \mathrm{a}}, \mathrm{H}_{1 \mathrm{~b}}\right.$ dan $\left.\mathrm{H}_{1 \mathrm{c}}\right)$ dan $\mathrm{H}_{2}$ diterima.

Peristiwa perundingan perang dagang Amerika dan China dilaksanakan pada tanggal 10-11 oktober 2019. Peristiwa tersebut merupakan fase pertama dari kesepakatan antara AS-China untuk mengakhiri gejolak perang dagang antara kedua negara tersebut. Peristiwa perundingan ini merupakan salah satu peristiwa terpenting bagi AS dan China dikarenakan gejolak perang dagang antara kedua negara tersebut yang sudah mulai memanas sejak awal tahun 2018. Perang dagang antara AS dan China sangat mempengaruhi volatilitas harga saham.

Menurut Hartono (2017) menyatakan bahwa pasar saham memberikan reaksi positif terhadap suatu pengumuman maka pengumuman tersebut memiliki kandungan informasi. Jadi, hasil pengumuman pada peristwa perundingan perang dagang Amerika dan China memiliki kandungan informasi dikarenakan pasar saham Amerika, China dan Indonesia bereaksi terhadap hasil pengumuman pada peristiwa tersebut.

Pasar yang efisien adalah jika harga-harga sekuritas mencerminkan seluruh informasi yang tersedia (Fama, 1970). Dari hasil penelitian ini mengindikasikan bahwa harga sekuritas pada pasar saham Amerika, China dan Indonesia di sekitar jendela peristiwa mencerminkan seluruh informasi yang tersedia oleh peristiwa perundingan perang dagang AS-China pada 10-11 oktober 2019 lalu.

Secara teoretis penelitian ini dapat memberikan tambahan pengetahuan dan wawasan yang lebih luas mengenai studi peristiwa (event study). Berdasarkan hasil penelitian yang telah dilakukan dapat diketahui bahwa secara teoritis, penelitian ini mendukung teori efisiensi pasar dan kandungan informasi. Penelitian ini dapat menjadi acuan pertimbangan bagi para investor untuk memprediksi harga saham di masa mendatang dan kemudian dapat mengambil keputusan terhadap suatu peristiwa yang terjadi. Selain itu, penelitian ini dapat memberikan kontribusi dalam tambahan ilmu pengetahuan dan pemahaman kepada peneliti-peneliti berikutnya.

\section{SIMPULAN}

Terdapat reaksi pasar di pasar saham Amerika, China dan Indonesia terhadap perundingan perang dagang AS-China. Dan terdapat perbedaan reaksi di antara pasar saham Amerika, China dan Indonesia terhadap perundingan perang dagang AS-China. Bagi para investor dan calon investor diharapkan mampu menyimak dan menganalisis peristiwa yang terjadi agar dapat mengambil 
keputusan secara tepat dalam berinvestasi. Bagi peneliti selanjutnya, dikarenakan penelitian ini meneliti tentang perundingan perang dagang fase yang pertama, oleh karena itu, diharapkan untuk meneliti tentang perundingan perang dagang fase yang kedua dan membandingkan reaksinya dengan fase yang pertama. Penelitian selanjutnya juga diharapkan dapat menambah cakupan populasi dan sampelnya.

\section{REFERENSI}

Alwi, I. Z. (2003). Pasar Modal: Teori dan Aplikasi. Nasindo Internusa.

Armstrong, C. S., Barth, M. E., Jagolinzer, A. D., \& Riedl, E. J. (2010). Market reaction to the adoption of IFRS in europe. In Accounting Review. https://doi.org/10.2308/accr.2010.85.1.31

Beaver, W. H. (1989). Financial Reporting: An Accounting Revolution. Prentice Hall.

Caskey, J., Hughes, J., \& Liu, J. (2012). Leverage, excess leverage, and future returns. Review of Accounting Studies, 17, 443-471. https://doi.org/10.1007/s11142-011-9176-1

Chen, J. (2019). Trade War. https://www.investopedia.com/terms/t/tradewar.asp.

Egger, P., \& Zhu, J. (2019). The US-Chinese Trade War: An Event Study of StockMarket Responses. Bank Of Finland.

Fama, E. F. (1970). Efficient Capital Market: A Review of Theory and Empirical Work. The Journal of Finance, 25(2), 383-417.

Grewal, J., Riedl, E. J., \& Serafeim, G. (2019). Market reaction to mandatory nonfinancial disclosure. In Management Science. https://doi.org/10.1287/mnsc.2018.3099

Hartono, J. (2010). Metodologi Penelitian Bisnis Salah Kaprah Dan Pengalaman Pengalaman. Yogyakarta: BPFE.

Hartono, J. (2017). Teori Portofolio dan Analisis Investasi. BFPE.

Hasdwi Putra, I. M. D., \& Dwija Putri, I. G. A. M. A. (2018). Analisis Reaksi Pasar Sebelum dan Sesudah Pengumuman Kemenangan Donald Trump Menjadi Presiden Amerika Serikat. E-Jurnal Akuntansi, 23(1), 406. https://doi.org/10.24843/ eja.2018.v23.i01.p16

Havráneková, M., \& Dvorský, T. (2019). The United States-China Trade War. Cesko.

Huang, Y., Lin, C., Liu, S., \& Tang, H. (2018). Trade linkages and firm value: Evidence from the 2018 US-China trade war.

IMF. (2019). Global Manufacturing Downturn, Rising Trade Barriers. World Economic Outlook.

Knauer, T., \& Wöhrmann, A. (2016). Market Reaction to Goodwill Impairments. European Accounting https://doi.org/10.1080/09638180.2015.1042888

Kori, M. O. D., \& Rasmini, N. K. (2017). Struktur Good Corporate Governance sebagai Pemoderasi Pengaruh Asimetri Informasi pada Manajemen Laba. EJurnal Akuntansi Universitas Udayana, 21(1), 144-172.

Ozturk, S., \& Altinuz, B. (2019). the Effect of Us-China Trade Wars on Shanghai Stock Exchange Composite Index AbdÇinTicaret Savaşlarinin Şangay Menkul Kiymetler Borsasi. June, 59-69.

Ratnaningsih, N. M. D., \& Widanaputra, A. A. G. P. (2019). The reaction of 
Indonesian capital market to political event the announcement of Indonesia presidential election 2019 results. International Research Journal of Management, IT and Social Sciences, 6(6), 87-94. https://doi.org/10.21744/irjmis.v6n6.765

Stanley, M. (2019). Morgan Stanley: Ekonomi RI Cuma 5 Persen Karena Perang Dagang.

https:/ / www.cnnindonesia.com/ekonomi/20190812111857-532-

420459/morgan-stanley-ekonomi-ri-cuma-5-persen-karena-perang-dagang.

Diakses pada tanggal 24 September 2019

Tandelilin, E. (2010). Portofolio dan Investasi (Edisi Pertama). Kanisius.

Tri, U. L. (2019). Pengaruh Peristiwa Perang Dagang AS-Cina Terhadap Abnormal Return dan Abnormal Trading Volume Activity Di Bursa Efek Indonesia (BEI). Universitas Negeri Malang.

Wahyudhi, P. S., \& Agung Suaryana, I. G. N. (2019). Reaksi Pasar Atas Kesepakatan Investasi Bidang Infrastruktur dalam Pertemuan International Monetary Fund-World Bank 2018. E-Jurnal Akuntansi, 27(1), 594-643. https://doi.org/10.24843/ eja.2019.v27.i01.p23

Wahyudi, K., \& Putra, I. N. W. A. (2020). Perbandingan Reaksi Pasar pada Perusahaan LQ45 dan Non LQ45 atas Pengumuman Stock Split. E-Jurnal Akuntansi, 30(2), 307-318. https://doi.org/10.24843/eja.2020.v30.i02.p03 